\title{
Indonesia
}

\section{Dancing in the dark}

\section{Andreas Harsono}

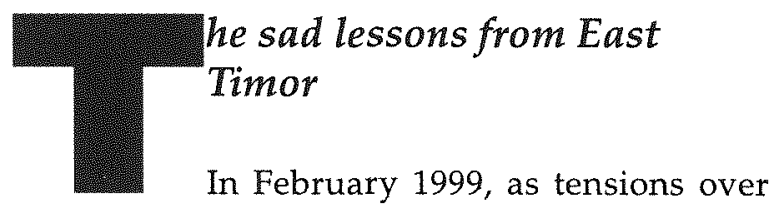

East Timor were building, scores of personally addressed faxes went out to Australian journalists, bringing a message of death into their offices and homes.

An Australian journalist would suffer the ultimate sanction-murderas a protest against Australia's role in urging Jakarta to approve a ballot on independence which would cut the restive province free from Indonesian control. The threat to the press was then expanded to take in Australian diplomats and Australian Foreign Minister, Alexander Downer, too, was shown a written 'death notice' by two commanders of pro-Jakarta militia units from East Timor during a visit to Jakarta. The militia units, Mr Downer said at the time, were 'very aggressive and very angry' and vowed to make a bloody 'sacrifice' over Australia's policy switch on East Timor, which prompted the then Habibie government to approve United Nations' supervised ballot. But, there was still a sense of disbelief that in post-Soeharto Indonesia that such blatant terror tactics could be used against the media, and-in particular-foreign reporters. Under the former authoritarian President Soeharto a number of Indonesian journalists had died mysterious deaths which were never properly investigated, silenced for their part in challenging the power élite within their own society.

However, under the supposedly reformist government of President, Dr B. J. Habibie, and with the nation virtually bankrupt and relying on a massive International Monetary Fund bail-out, the calculated murder of a foreign journalist would be likely to attract considerable pressure in western nations to cut ties with, and suspend this aid to, Jakarta. 
As a tactic, the threat to journalists was hardly new. Prior to the 1975 invasion of East Timor by Indonesian troops-who forcibly annexed the former Portuguese colony as Jakarta's 27th province-the Indonesian military broadcast similar menacing messages across the border. Six Australian journalists who stayed behind as the Indonesia military advanced were murdered, five at Balibo and one on the docks in Dili. Their deaths soured bilateral relations between Australia and Indonesia for decades and, in some ways, have coloured Australian reporting on Indonesia. There is ongoing debate over how the men died, but it now seems clear that five members of two televisions crews seeking refuge in Balibo were killed by an Indonesian special forces unit ahead of the invasion, and the sixth, $\mathrm{ABC}$ journalist Roger East, was executed in Dili, according to published accounts of interviews with witnesses.

The aim of the death threats both in 1975 and 1999, said James Dunn, former Australian diplomat and author of 'Timor: a people betrayed', was 'to scare journalists away so that the military could operate with impunity, without witnesses'. In 1975, he said in a recent interview, the tactic was largely successful. The Indonesian military invasion, one of great brutality, was carried out without the watching eyes of satellite TV or foreign reporters.

But, in 1999, both politics and technology had already changed the face of Indonesia and the international media. Hundreds of foreign and local journalists moved into Dili, many with their own satellite phones and satellite dishes to uplink photos, images and stories. In the lead up to the UN-supervised ballot, the violence by pro-Jakarta militia units against journalists escalated. First, journalists were merely stopped at roadblocks and machetes and knives were waved angrily in the air. Then journalists were chased with weapons and beaten. Specifically, the targets were western journalists-symbols of western governments pressuring Indonesia over human rights abuses and supporting the right of the East Timorese to choose their own fate.

But carnage was unleashed when the 30 August 1999 ballot to end Indonesia rule was supported, with 78.5 per cent in favour of independence according to the UN-organised vote (UN Press Release SC/ 6721,3 September 1999). So terrifying was the violence, that the majority of foreign and local journalists did flee and-in a sense-the Indonesian military and their militia allies were able to plunder and pillage at will, 
either in a losers' orgy of revenge or as a calculated scorched earth message to other restive provinces.

In the UN compound in Dili, however, enough foreign journalists and international staff stayed to keep lines open to the world. On satellite telephones, with bullets flying overhead, those huddling inside the compound told the story as best they could both from the accounts of those who came to seek refuge inside, and their own first hand experiences. The militia and their allies in the Indonesian military cut all telephone links in the province, even the mobile phone network, destroyed the radio relay stations and switched off the power. But, battery powered satellite phones could not be cut. 'We were getting a call every 90 seconds or so, 24 hours a days, from all over the world', said one UN staffer. As such, the story of East Timor in 1999 was dramatically different to the virtual silence which met the invasion in 1975. Headlines all over the world urged governments to pressure Jakarta and, finally, in the last week of September 1999, peacekeepers were allowed in.

Tragically, one day after Australian-led peacekeepers had fanned out across Dili and an end to the violence was finally in sight, militia units, reportedly mixed with Indonesian troops, led two direct attacks on western journalists. Sander Thoenes, a Dutch national, who worked for the Financial Times, was brutally hacked to death just a couple of blocks away from the ruins of the Turismo Hotel where most of the press were staying. He was a tall, blonde young man, obviously a westerner. Two British journalists escaped a similar attack, but their driver was disfigured and their translator kidnapped, presumed to have been murdered. Several days later a 26-year-old Indonesian cameraman, Agus Muliwan, who worked as a stringer for the Tokyo-based Asia Press, was also killed by a mixed unit of militia and Indonesian troops. He was apparently targeted because he was travelling with a group of East Timorese Catholic clegy.

In war zones journalists are not offered, nor should they expect, any special protection, unless they choose to travel directly under the supervision of a military force. But, in East Timor in 1999 the media was part of the conflict, because of the perception on the Indonesian side that international reporting from East Timor over the years was largely responsible for exposing decades of serious human rights abuses and maintaining pressure for independence. 
Much of Indonesia's political and military power élite were both furious over and humiliated by the results of the UN vote, which so overwhelmingly rejected Indonesian rule despite the militia's pre-poll terror campaign. For over 23 years the Indonesian government had told the world that the East Timorese wanted them there. With the arrival of Australian-led peacekeepers the Indonesian media was again cranked up, this time in the name of nationalism.

The government wire service, Antara, which had been moving towards a more independent editorial position since the fall of Soeharto, led the condemnatory reporting of Australia's actions in East Timor, claiming gross human rights abuses on the part of Australian troops. Local newspapers carried photographs of supposed victims of Australian atrocities (actually the corpses of those murdered by pro-Jakarta militia units) and rent-a-mob demonstrators besieged the Australian Embassy. Again, the media was a crucial element to this new bilateral standoff. In a statement issued in October 1999, the Institute for the Studies on Free Flow of Information, said,

We demand that the Indonesian intelligence community end its practice of infiltrating the press corp...this results in reports which sound like propaganda and hurt the reputation of Indonesia in the international community. Let journalists look for the truth and do their job. It is wrong for the intelligence community to fill the media with lies that only serve to inflame anti-Australian sentiment (Goenawan Mohamad 1999).

However, the Institute also bemoaned the absence of Indonesian journalists on the ground in East Timor and difficulties in complying with Darwin registration requirements. At the same time, however, decades of information control under Soeharto meant few Indonesians have much sympathy for the East Timorese. Too often they see the East Timorese as voracious and ungrateful consumers of aid budgets-an image promoted in Indonesian government propaganda about the conflict. On East Timor, the manipulation of the local press was not difficult.

In the bigger picture of political developments in Indonesia, East Timor may historically be viewed as the last desperate attempt by elements of the Indonesian military and political élite to maintain control over the press. At a national level censorship was formally defeated with the 
collapse of the Soeharto regime in May 1998. Advances in information technology, particularly the Internet, contributed significantly to an underground alternative news network in the last years of the Soeharto regime, and offered practical communications tools for the organisation of mass protests.

However, those accustomed to power rarely exit the stage overnight. When the state relinquishes control of the press, particularly after years of censorship which have stifled the development of an independent media industry, a vacuum is left behind. Into this vacuum rush any number of forces-elements of the old power élite such as the military, businesses or politicians. The result may be that censorship is replaced by corruption and unprofessional practices as the new forces in society shake out and a new power structure is built.

In October 1999 incoming President Abdurrahman Wahid, announced his new Cabinet. Missing, for the first time in more than three decades, was a Minister of Information. Stunned, hundreds of employees of the now defunct Department of Information, the Minister had controlled, spilled out onto the streets to try to protest. Under former President Soeharto they had been amongst the bureaucracy's most powerful figures, charged with monitoring both the local and foreign media and dishing out the appropriate censures, such as the suspension of licences, harrassment and cancellation of visas. Control of information was central to Soeharto's hold on political power. Now, they were to be unceremoniously absorbed into other government departments. 'Information is not the Government's business, it is the people's business', said President Wahid (1999).

The dismissal of the censors is an enormously symbolic step in the move towards press freedom, but most media analysts agree that Indonesia still faces a myriad of structural, practical and historical barriers to the effective operation of a free and independent media.

\section{Indonesia's presidents inherit colonial controls}

The annals of the Indonesian media date back to 1744 when a Dutch national in Batavia, the Dutch-name for today's Jakarta, published the Bataviase Nouvelles. The paper was the first publication in the Dutch East Indies, and primarily chronicled business activities and the arrivals and 
departures of ships through the port. But, the Dutch, fearing the potential for criticism of their tough administration in the resource-rich colony, closed the newspaper within two years and discouraged other members of the public from taking similar initiatives. It was not until five decades later that a Dutch language publication, the Bataviaasche Coloniale Courant, was accepted, and members of society, including local Indonesians and Chinese immigrants, began to involve themselves in newspapers.

By the beginning of the 20th century many Indonesians appreciated the power of the media to spread the message of the independence movement, realising the Dutch administration's early fears that newspapers could be turned against them. Many Indonesian freedom fighters were also writers, including Soekarno who was to become an independent Indonesia's first President following the end of World War II. Indonesia's most widely recognised novelist, Pramoedya Ananta Toer, also used a Javanese journalist as the inspiration for his main character, Minke, in his Buru Tetralogy series of novels which have been translated and distributed internationally, but were banned in Indonesia until 1999. The novels are set in the 1900s on the Dutch-ruled island of Java and Minke is based on journalist Raden Mas Tirto Adisoerjo, who published the Malay-language Medan Prijaji newspaper and was repeatedly imprisoned by the Dutch for his writings.

Writers such as Adisoerjo and Soekarno created so many problems for the Dutch government that in 1931 it introduced a law (pressbreidel ordonantie) which allowed the Dutch Governor-General to temporarily ban a publication (for up to eight days) which 'disrupted public order'. If the banned publication continued to 'produce a disturbance', the Governor-General could implement a second banning of up to 30 days. The Dutch colonial government also introduced the notorious thate sowing' articles (haatzaai artikelen) of the Dutch Criminal Code, regularly used to punish independent journalists. Three of these articles forbid the publication of statements that incite feelings of hostility, hatred or contempt towards the government' and prescribe jail terms of between four-and-a-half and seven years for doing so. Another article, which provides for up to 18 months imprisonment for 'insulting a government authority or body', has also been used.

Ironically, these articles were adopted by the new independent Indonesia. The Indonesian governments of both Soekarno (1945-65) and 
Soeharto (1966-98) simply made some modifications in the language, for example, changing the word Governor-General to President. The hatesowing articles were used extensively during Soeharto's rule.

When the Japanese military occupied Indonesia in March 1942, the military administration immediately closed down all the local newspapers and then permitted only a handful to re-open. Unlike the Dutch rulers, who preferred punishment over preventive measures, the Japanese introduced a publishing licencing procedure to control the media. Although the Japanese surrendered and pulled out three years later, the licencing procedure, too, was incorporated into the armoury of the independent Indonesian government and was used particularly vigorously by former President Soeharto (Luwarso 1999).

Soekarno and Mohammad Hatta declared Indonesia's independence on 17 August 1945, establishing a new constitution which states, 'Freedom of speech and of the press and similar freedoms shall be provided by law'. But in practice, severe restrictions on freedom of speech, assembly and association, including a raft of regulations and laws, have been imposed in post-independence Indonesia.

The departure of the Japanese and the declaration of independence brought Indonesia a brief media honeymoon, with many new newspapers emerging. But Soekarno, the freedom fighter and writer, resorted to authoritarian measures to shore up his own power base and by 1959 had declared martial law, giving the military the right to censor the media. Soekarno controlled the press but failed to control the economy, and with inflation spiralling out of control and the people hungry, he was toppled in a military-sponsored coup in 1965, accused of links with the growing communist movement.

A second false dawn for the media followed the ascension of the then Major-General Soeharto to the Presidency. In 1966 the parliament passed Indonesia's first Press Law which provides that 'no censorship or bridling shall be applied to the national press' and calls on the press to 'fight for truth and justice based on freedom of the press'. But a caveat was inserted denying such freedoms to those publications 'conflicting with the state ideology, Pancasila, such as those inspired by Communism, Marxism and Leninism'. Soeharto, too, proved to be an authoritarian strongman and by 1974 had consolidated his political power. Student protests that year were brutally suppressed and more than a dozen newspapers were closed 
because of their coverage of the uprising. Soeharto's mantra was stability and economic development ahead of democracy and transparency, a formula which initially fuelled economic growth and made Indonesia the darling of international institutions despite tough restrictions on freedom of speech.

In 1982, Soeharto upgraded the Japanese-inspired licencing requirements for publications, introducing an even more restrictive Press Publications Business Licence and the proviso that the press must be 'free and responsible'. Soeharto and his assistants were fond of the word 'responsible' as it allowed them to impose informal censorship on the media on a day-to-day basis. The satirically named 'telephone culture' was born in this era, referring to telephone calls to editors from Ministry of Information officials or the military 'advising' them on how to report on particular issues (Schwarz 1994). Officials also made unexpected visits to newspaper offices to persuade editors not to run a particular story. This form of censorship relied on the implied threat that a publication's licence would be withdrawn, making it both confusing for editors and effective for the government because there was no clear line over which editors should not step. Known taboos included coverage of the Soeharto family's business dealings and those of other corrupt officials, but editors often self-censored beyond these limits. For journalists and editors who crossed the invisible line there was personal financial ruin, unemployment or worse-harassment, intimidation, imprisonment or, sometimes, death.

\section{Soeharto's crackdowns}

For foreign journalists similar threats were used-expulsion and the closure of the bureau. All Australian journalists were banned from Indonesia in 1986, over a Sydney Morning Herald article about the accumulated wealth of the Soeharto clan. As Australian journalists were gradually readmitted over the next decade, it was made clear they were expected to 'understand' the Indonesian government's perspective. Quiet pressure was also applied on Australian journalists by their own diplomats, who saw the press as one of the most difficult bilateral issues between Jakarta and Canberra. Within the then all-powerful Department of Information in Jakarta censors poured over copies of local and foreign articles, looking for references to bring to the attention of their bosses for 
their potential offence to the ruling élite. Foreign journalists were also banned from travelling to the troubled provinces of East Timor, Irian Jaya and Aceh or were expelled if caught without a special permit.

One of the most dramatic - and eventually costly_decisions made by the Soeharto administration was to close the popular and relatively courageous, Tempo magazine and two other weeklies, Detik and Editor, in 1994 (Lindsey 1999). Information Minister, Harmoko, himself a former journalist, ordered the closures, accusing the publications of pitting government officials against each other over a controversial purchase of East German warships. At this time Indonesian society was feeling pressures for openness that a market-based economy delivering rapid growth, brings. The magazine closures prompted nationwide protests of journalists, students, lawyers, artists and other professionals and forced key groups of media professionals out of the industry at a time when there was growing public demand for alternative information sources

The state-sponsored Indonesian Journalists' Union (PWI) issued a statement saying it could 'understand' the government's decision, angering many journalists and splitting the profession into two groupsthose who were prepared to continue to toe the line and protect their own personal interests and those who were willing to take some risks. Many younger journalists formed an illegal union, called the Alliance of Independent Journalists (AJI), to fight for press freedom and to offer advocacy services for media workers (Luwarso 1999). It gained considerable support in Jakarta and other large cities such as Surabaya, Yogyakarta and Bandung and challenged the government's licencing requirements by publishing an underground newspaper, Suara Independen (Voice of Independence). The state-sponsored union, came down heavily on the government's side calling for a ban on the employment of rebel journalists associated with the publication. Three AJI journalists were eventually jailed for 'sowing hatred' against government officials and publishing an unlicenced newspaper. But, perhaps more importantly, hundreds of rebel journalists were barred from the industry (International Centre Against Censorship 1996).

At that time former Tempo editor, Goenawan Mohamad, began assisting young, unemployed journalists to use their time more profitably. 'Let us not curse the darkness, let's light the candles', was a popular slogan in the early days of the underground press. While some ex-Tempo journalists 
apologised and returned to the state-controlled press, many did not. Instead, they set about trying to create a genuine political movement, studying pro-democracy movements elsewhere and establishing networks of their own.

One of the critical tools of the mid 1990s was the Internet. Some former Tempo journalists established Tempo Interaktif which became an electronic version of the banned magazine. Another former Detik journalists set up 'detik.com', which offered a free daily service of uncensored news. For those not connected to the Internet there was a printed version available on a confidential mailing list.

According to Tedjabayu Basuki, an Internet specialist at the Jakarta Institute for the Study of the Free Flow of Information, it is difficult to pinpoint exactly when the Internet was transformed into a weapon of dissent in Indonesia. But, the banning of the weeklies was a significant turning point. However, Indonesians abroad had discovered the Internet's potential earlier than their compatriots back home. Indonesian students overseas set up many online conferences, discussing political developments in Soeharto's Indonesia.

Then, there was also John McDougall, an American Indonesianist based in Maryland, who had established his own information company in 1984. McDougall's firm specialised in research findings and other quality articles about Indonesia. Initially, he sold the service commercially but, encouraged by such an enthusiastic response, he established a free Internet-based mailing list in 1990 called Apakabar (literally meaning, 'How are you?'). It offered a wide range of views from the most radical to the conservative, from pro-democracy activists to military intelligence officers masquerading as Internet enthusiasts. It also distributed various news reports from a wide range of mainstream media sources, both foreign and Indonesian, such as Kompas, Forum Keadilan (Justice Forum), the Sydney Morning Herald, the Far Eastern Economic Review, the Asian Wall Street Journal and the New York Times. A number of Indonesian journalist-based news groups also joined the mailing list, distributing their news reports, without the censorship of Indonesia's mainstream media newsrooms.

'The Apakabar mailing list subsequently played a central role in spreading up to date information about Indonesia' (Basuki 1999). The number of actual recipients was quite small, but photocopy machines were used to boost circulation. Apakabar had also inspired Indonesian Internet 
users to establish their own mailing lists. The response from the Soeharto government to Internet sites appeared to be largely ineffective. Soeharto's regime was accustomed to wielding a large black pen to black out offending articles in foreign publications, not chasing challenging views across an international electronic network.

Within Indonesia student publications were also a source of alternative views. Some, such as the Balairung magazine and the Bulaksumur tabloid in Yogyakarta, established websites to enlarge their audiences. Student newspapers are, of course, mostly read by students and swapped between campuses. However, the Internet was later used as a powerful organising tool for student protests against the Soeharto regime-from informing foreign correspondents of the latest protest sites to appealing for food and drinks for the exhausted demonstrators.

Alternative media outlets began to play a crucial role in mid 1996 when the Soeharto government organised a rebel conference of the Indonesian Democratic Party (PDI) to topple its popular chairwoman, Megawati Sukarnoputri. The reason behind this clumsy political manoeuvre was Soeharto's fear of competing against Megawati, the eldest daughter of founding President Soekarno, in elections scheduled for 1997. The Internet mailing lists provided the public with information about the plot to topple Megawati, and her enraged supporters rioted for two days in Jakarta following her ouster-protests which can, in retrospect, be seen as the beginning of the end of Soeharto.

The alternative media proved to be an effective medium for Megawati, who has more than a dozen websites dedicated to her struggle. Soeharto forced Megawati out of the PDI, and banned her from politics, but failed to sideline her from a growing national democratic struggle. From a relatively untested party leader, the housewife-turned-politician became a national symbol of integrity, against the backdrop of the corrupt Soeharto regime. Her hugely popular party won the largest share of the votes in the first post-Soeharto election in June 1999, with 34 per cent. She was relegated to the Vice-Presidency because of a deal cut within parliament to give the top job to her old friend, Muslim leader, Abdurrahman Wahid.

The Internet also provided the public with information about a wide range of Soeharto-linked businesses. Journalist-turned-activist George Junus Aditjondro, from his self-exile in Australia, used the Internet to 
post details of dozens of companies controlled by the Soehartos, as did other activists. This information was downloaded and circulated in photocopy form while Soeharto was still in power. After his resignation, the mainstream international media, including TIME magazine, began to quote Aditjondro's research as publishing houses raced to print his books.

\section{The crisis hits, the students hit back}

When the East Asian currency crisis hit Indonesia in August 1997, the rupiah began its spectacular collapse, dropping from 2,400 to the US dollar to a low point of 17,000 in January 1998 . Without economic development, the Soeharto mantra was meaningless. What point bowing to draconian political controls when the rice bowl was now empty. However, Soeharto appeared to be unable to understand the inevitability of his own fall, as did many members of the ruling élite and the main stream media. In March 1998, the Indonesian parliament elected Soeharto for his seventh successive five-year term. His new cabinet was filled with cronies, including his wealthy eldest daughter, Siti Hardiyanti Rukmana, and his golfing buddy, tycoon Bob Hasan.

The students reacted and a wave of protests began-at first cautiously, with sit-ins confined to campuses, but gradually spreading out onto the streets. At this time the Internet became more and more important, as an organising tool and as a means of spreading the opposition's views. When military sharpshooters killed four students fleeing riot troops at Trisakti University on 12 May 1998, the regime had crossed the public's line. Massive riots across Jakarta ensued and Soeharto was forced to resignthe eyes of the world's media were on the tanks and troops roaming the streets of Jakarta and the airport filled with evacuating foreigners.

When the line had been crossed Soeharto's power structure simply collapsed. Censorship can only be imposed when a regime holds genuine power to punish or hurt. With chaos on the streets the mainstream Indonesian media jumped into the fight, on the other side, broadcasting images of the students' protests and-arguably-contributing to the success of the students' campaign. The usually conservative, governmentcontrolled Televisi Republik Indonesia (TVRI) even repeatedly ran an eulogy of the dead students, galvanizing public awareness of the tragedy in 
Jakarta, and indicating that those at the top were no longer in control. Many government officials and military officers did not understand the winds of change. They harassed and intimidated journalists right up to the last minute, when Soeharto offered his humiliating resignation to his people, in a live national broadcast.

And even beyond Soeharto the dark elements of the military continue to intimidate media figures. Military elements were behind the arson attack on the home of Riza Primadi, the news director of Surya Citra Televisi (SCTV), when he was leading his journalists in a live television broadcast of the shooting of protesting students in November 1998 by riot troops. Primadi, a former BBC journalist, is known to be an independent producer. Many of his reporters were threatened but the station continued to lead the news coverage on such formerly taboo issues as military violence against civilians, the fall of Soeharto and consequent efforts to bring Soeharto and his children to justice.

On the part of the Soeharto regime, the dramatic events of May 1998 illustrated a failure to understand the international and local media, and the impact the media, and information technology, could have on politics in the late 1990s. The controls in place-such as visa restrictions for foreign journalists and threats to suspend the licences of local publications-relied on a bureaucracy which believed in the power of its political leaders. It also relied on that bureaucracy's power to control communication. But as technology developed this simply became more and more impractical. As the political power visibly crumbled, immigration officials happily waved through scores of foreign televisions crews on tourist visas, censors were unable to make decisions, and the regime found itself totally isolated from the media. Decades of telling the media what to report, and refusing to be questioned meant there was no infrastructure in place, such as press officers to provide an 'official' version of events, to put a more favourable spin on the crisis. The students and the opposition had centre stage, almost by default. Information controls had totally collapsed. Chanting students waving colourful banners facing down riot troops and a city devastated by riots were such powerful images that government restrictions on uplinking TV footage from Indonesia were reduced to a joke. Technology was such that foreign TV crews had the capacity to by-pass officially approved transmitters anyway. 


\section{Habibie bows to the inevitable}

When incoming President Habibie took over in May 1998, he had little choice but to liberalise the country's political system, to hold democratic elections, release political prisoners and to support a free media. Independent organisations found it difficult to believe that a Soeharto crony such as Habibie, who spent 15 years serving in Soeharto cabinets, would implement the promised reforms.

But to the surprise of many, Habibie tried to keep his promises. He once told a delegation of foreign journalists, 'I will never, never tolerate an Indonesian government that interferes with the freedom of the press. Freedom of the press is very important. Not only for politics but also for economics.'

Then, just a month after taking up the position as Habibie's Information Minister, Muhammad Yunus announced that the media would be open to all. Journalists would be permitted to establish independent unions and professional organisations, undercutting the monopoly of the statecontrolled Indonesian Journalists Association (PWI). Newspapers would no longer need political connections to secure a license to run a printing press. Private radio stations could also reduce the compulsory relay of the Radio Republik Indonesia (RRI) (government radio) news reports from fourteen to three times per day, a welcome relief for millions of Indonesians after decades of dry, boring government propaganda.

The result-many new newspapers immediately entered the market. One year after Soeharto's fall, the Ministry of Information had issued more than 1000 press licenses-four times more than the Soeharto regime issued in over 30 years in power. Yunus even suggested that the ministry be abolished, as it since has been, saying that it was nothing more than a state apparatus to control the press.

Even more so than Habibie, many were skeptical about Yunus' sincerity. Yunus, a three star General, was allegedly directly involved in the 1975 murder of the five Australian journalists in Balibo, where he served as a special forces officer. But his decisions did spark a rush of new national and community newspapers and publications, not only in Jakarta, but in many smaller cities and towns. Private radio stations raced into news reporting, challenging an area which the government-controlled RRI had monopolised since 1945. Jakarta-based stations such as Trijaya, Sonora and 
Elshinta began producing their own news reports. Elshinta went even further, with live broadcasts of the BBC Indonesian Service since November 1998. The move was trailed by other private radios in other cities such as Prima in Banda Aceh or Smart FM network in Palembang, Manado and Ujungpandang. Other Indonesian-language programs of the Voice of America, Deutche Welle, Radio Australia and Radio Netherlands were also broadcast live in Indonesia for the first time in history. These were bold programming decisions in a nation where many government officials and army officers still consider the respected international radio services 'too critical'.

But the new openness has also sparked sensationalism. Many of the new tabloids publish speculative and irresponsible reports, which freely mix facts with opinion and conjecture. Tabloids tend to spice up their reports with sex and crime. The Jakarta police charged several editors with distributing pornography in June and July 1999, questioning voluptuous actresses like Sophia Latjuba, Inneke Koesherawaty and Sarah Azhari for posing nearly nude on magazine covers in a predominantly Muslim nation. The editors denied the charges, saying the photographs were used for aesthetic, not pornographic, reasons. The Warta Republik tabloid, for example, published a December report on how former Vice President Try Sutrisno and former Defense Minister Edi Sudrajat had allegedly competed to date a widow. Neither Sutrisno nor Sudrajat were interviewed-and neither was the widow. The tabloid later admitted that it did not even know the whereabouts of the widow. The aggressiveness of the new press can be startling, in a nation emerging from decades of control. One paper is called simply Oposisi (Opposition), and its regular broadsides against Soeharto's legacy of corruption and nepotism leave readers no doubt about what it is opposed to. Another is called Gugat which means, 'accuse' in Indonesian. The tabloid proudly claims its motto as 'Trial by the press'.

The result of this new culture of muckraking is a rash of lawsuits. The Jakarta military command, for example is suing the Tajuk bi-weekly. The military accused the magazine of tarnishing its reputation in a report which said former Jakarta commander Major General Sjafrie Sjamsuddin, a close associate of Soeharto's son-in-law Prabowo Subianto, was involved in instigating the massive riots of May 14-16, 1998. Prabowo himself was transferred from his position one day after the fall of his father-in-law 
amid widespread speculation he was also involved in the kidnapping, torture and illegal detention of human rights activists as well as instigating the riots, in which more than 1,200 people died. Arnold Baramuli, an associate close to Habibie, also sued the Gamma magazine for publishing a taped conversation between Baramuli and a businessman who had allegedly help Baramuli to divert funds from a bank to the Habibie campaign. The police also questioned editors of the Panji magazine over a leaked telephone conversation between Habibie and then AttorneyGeneral Andi Muhammad Ghalib. Habibie allegedly ordered Ghalib to 'pretend' to be going through the motions of questioning Soeharto, to appease the public as calls continued for Soeharto to be brought to justice.

Such stories are, understandably, a spectacular departure from the bland, censored fare of 1998. But the problem for the Indonesian media post-Soeharto is that new press freedoms are not backed up by a sound legal system, nor the checks and balances that a Press Council, for example, could provide. At the same time decades of hand feeding a compliant press has created an industry vulnerable to new forces of manipulation:, particularly money.

Take, for example, the concerns of Luzi Diamanda, a former journalist who now heads the Voice of the Public, a local media watch dog body in the provincial city of Padang, on the island of Sumatra. Every time a new newspaper hits the stands she becomes more concerned, she says. Most of the new publishers do not pay their reporters a fair salary, and the reporters themselves have little experience of how to conduct interviews and produce independent stories professionally. The main objective of the new publications is to increase the business influence or the political muscle of their owners, not to contribute to the flowering of a pluralistic media in post-Soeharto Indonesia.

'These journalists end up working without journalistic ethics. They work only to collect envelopes', she says of the common practice of handing out envelopes of cash to journalists to cover official events or business news. So coloured by money has local reporting become, that a group of 14 journalists was attacked by 300 farm workers on a plantation near Padang in March 1999. The journalists had been 'invited' by a local business figure to witness a land appropriation case, one of the most sensitive issues in Indonesia because much land is occupied by illegal settlers. So biased was the coverage, the workers believed, that they were 
provoked to smash the windscreens of the journalists' cars and seriously injure two reporters. Three months later, Padang journalists went on 'strike', clearly having learnt nothing from the plantation confrontation. Their complaint was that West Sumarta Governor D. Dunidja had failed to provide adequate transportation for them during their latest field trip with him.

"The odds are that Indonesia will remain in a chaotic situation for some time', said editor Goenawan Mohamad, of the re-opened Tempo magazine, 'Violence will be a constant threat and we will be the sick man of Asia. That frightens and saddens me. The best thing the press can contribute is to develop a culture of transparency and accountability in the government.' Goenawan, whose magazine was published again in October 1998, said, 'I hope Tempo will become a vehicle to help defend and expand our freedoms'.

\section{Dancing in the dark}

The fall of Soeharto is not the end of the struggle. It fact, it is the beginning of a more complicated and time-consuming struggle to institutionalise democracy and freedom of expression. Early positive signs include the establishment of media watch groups like Diamanda's in ten cities-the Institute for the Studies of Information and Mass Media in Ujungpandang in southern Sulawesi, the Institute for the Studies of the Press and Information in Semarang, about 320 kilometers east of Jakarta. Other previously established players have also strengthened their networks. Independent journalist unions, like the AII, have established seven full branches and three smaller bureau in ten Indonesian cities. Student journalists are also learning to improve the quality of their reporting and analysis. But, there is much homework to be done and young journalists need to learn from the failure of their elders during the Soekarno and Soeharto eras-a task which runs counter to the culturally ingrained respect for one's elders.

Two of the most active organisations in advocating changes to media laws are the Jakarta-based Indonesian Press and Broadcasting Society (MPPI) and the Indonesian Newspaper Publishers Association (SPS). Interestingly, both PWI and AJI, who used to be at loggerheads, are now 
trying to work together under the MPPI umbrella. The four most urgent tasks are

- to change the Dutch and the Japanese-inherited laws on the media which include the hate-sowing articles, the publishing licence procedure, dozens of ministerial decrees on print, radio and film as well as the 1945 constitution on freedom of expression. The constitution should be amended to totally guarantee press freedom in Indonesia

- to strengthen media organisations as well as journalists' unions so they have the ability to defend newly established press freedoms. This strategy means that more media training is needed, especially for new journalists

- to set up independent media watch groups as well as newspapers ombudsmen. This proposal is based on the reality that information is power, and power can be corrupted. The media should be monitored and reprimanded if its uses its power corruptly. During the Soekarno and the Soeharto eras, their administrations took the role of controlling the media. Now who controls the media?

- to decentralise media concentration from the main island of Java to the other outer islands and small towns, thus providing more genuinely community-based services. By April 1998 the Ministry of Information reported 415 or 48.7 per cent of 852 publishing licenses issued by the government were for Jakarta-based publications.

Easier said than done. A transitional period always poses a very difficult question about how to draw the line between the past supporters of the status quo and the campaigners for democracy. In the post-Soeharto era many editors and journalists who complied with censorship are reinventing themselves as champions of media freedom. What role should they play? At the same time many of those who took the real personal risks of challenging Soeharto consider themselves heroes of the reformasi (reform) era and demand to be treated as such. But, courage, must be coupled with sound managerial skills and experience to produce new, quality media organisations. The situation is not black and white, but this political divide does complicate the picture.

In May 1999 two Indonesian journalist groups along with three other groups from Thailand and the Philippines helped set up a regional organisation to monitor abuses against the press in Southeast Asia and 


\section{Losing control}

strengthen press freedom in the region, '[i]t is time for Asian journalists to work together to build press freedom', said Kavi Chongkittavorn, the chairman of the Southeast Asian Press Alliance (SEAPA). Kavi, executive editor of Thailand's daily Nation newspaper, said it was up to Asian journalists to defend themselves 'from attacks and threats', saying SEAPA aimed to develop an information network to research press laws, access to information, ethics as well as intimidation of, and physical attacks on, journalists.

But, the reality on the ground is that transitions can be both chaotic and dangerous. As the new rules are written, the losers smart and plot. An Indonesian journalist was found hacked to death in August 1999 in the troubled province of Aceh, where horrendous human rights abuses by the military have been exposed both under Soeharto and during Habibie's rule. And so died Sander Thoenes in a senseless, tragic murder commited after Indonesia had already lost the war in East Timor.

\section{Media websites}

$X$-pos weekly print magazine (underground), apchr.murdoch.edu.au/ minihub/xp/

SiaR mailing list (online edn only and includes special sections on East

Timr, Aceh, Irian Jaya and Indonesian military), apchr.murdoch.edu.au/minihub/siarlist/maillist.html/

Indonesia-L mailing list (popularly known as 'apakabar' mailing list), www.indopubs.com/

Joyo mailing list (no official website, contains English-language

international media reports), joyo@aol.com/

Kompas daily newspaper, www.kompas.com/

Tempo magazine, www.tempo.co.id/

Republika daily, www.republika.co.id/

Media Indonesia daily newspaper, www.mediaindo.co.id/

The Jakarta Post, English www.thejakartapost.com/ 